
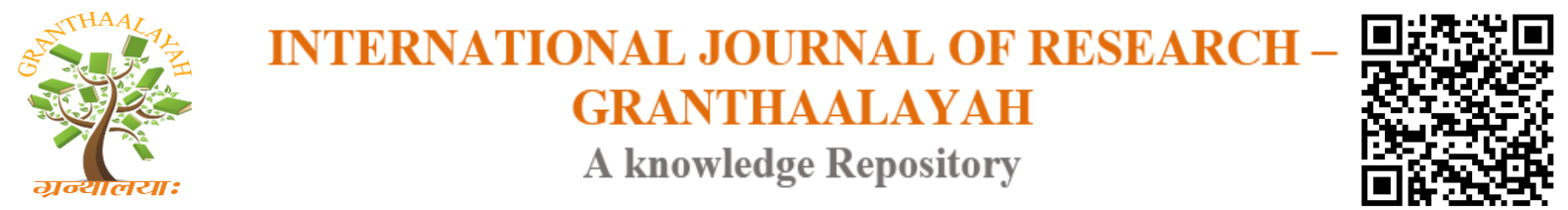

Science

\title{
INVESTIGATION OF HEAVY METAL CONTAMINATION IN THE ROADSIDE SOIL AT MORENA DISTRICT IN INDIA
}

\author{
Laxmi Kant Sharma ${ }^{* 1}$ \\ ${ }^{* 1}$ Department of chemistry, Ambah P.G. (Autonomous) College, Ambah, Morena-476111, M.P., \\ INDIA
}

DOI: https://doi.org/10.29121/granthaalayah.v4.i11.2016.2421

\section{ABSTRACT}

Pollution of natural environment due to release of heavy metals from various sources is a widespread problem throughout the world. This study explains the effect of heavy metal contaminants in Roadside soil of Morena district. Twelve air dried surface soil samples were collected from $50 \mathrm{~cm}-1 \mathrm{~m}$ (point $A$ ) and twelve from $30 \mathrm{~m}$ (point B) away from the roadside along a road with a distance of $50 \mathrm{~km}$. Heavy metals were found in both points with highest concentration at $50 \mathrm{~cm}$ - $1 \mathrm{~m}$ (point A). Roadside soil is a definite indicator of vehicular pollution from where the high degree of contamination, is expected. The presence of heavy metals like $\mathrm{Cu}, \mathrm{Cr}, \mathrm{Fe}, \mathrm{Pb}, \mathrm{Zn}$ and $\mathrm{Mn}$ in the roadside soil was also considerable.

Keywords:

Heavy metal, Roadside Soil, Atomic Absorption spectrophotometer (AAS), Morena, India.

Cite This Article: Laxmi Kant Sharma, "INVESTIGATION OF HEAVY METAL CONTAMINATION IN THE ROADSIDE SOIL AT MORENA DISTRICT IN INDIA" International Journal of Research - Granthaalayah, Vol. 4, No. 11 (2016): 72-76.

\section{INTRODUCTION}

Owing to the increasing traffic volume pressures in urban areas, the environments that are closer to the highways are subjecting to pollution from traffic emissions. Many studies have proved beyond doubt that the urban roadside environments are polluted by heavy metals [1-3]. Public motor roads affects natural environment to a large extent because automobile act as line sources of heavy metal pollutants [4]. The waste products from vehicles that ply highways contain some heavy metals inform of smokes. Emissions from exhaust pipes of automobile engine and contacts between different metallic objects in machines contain such heavy metals as lead ( $\mathrm{Pb})$, Zinc $(\mathrm{Zn})$, Iron(Fe), Copper $(\mathrm{Cu})$ and Cadnium $(\mathrm{Cd})$ and are major sources of pollution among soils [5]. Food chain contamination is one of the important pathways for the entry of these toxic pollutants into the human body [6]. The contaminants from automobile either accumulates on the soil surface or are moved down to deeper layers and eventually may change the soil physicochemical properties directly or indirectly. There have been several reports on roadside soils pollution [7- 
11] by heavy metals close to some major cities. Heavy metals in the soil can also generate airborne particles and dust which may affect the quality of air. Inhalation of substantial quantities of heavy metal particles over period of time may add to human body and constitute health risk.

\section{MATERIALS AND METHODS}

Morena is located at $26.5^{\circ} \mathrm{N} 78.0^{\circ} \mathrm{E}$. It has an average elevation of 177 metres (580 feet). Geographically Morena is an interesting place as Madhya Pradesh touches two neighbouring states i.e. Rajasthan and Uttar Pradesh here. Morena touches Dholpur (Rajasthan) in North-West and Pinahat (Agra, Uttar Pradesh) in North-East peripheries and is therefore, a semiarid area (Figure 1). This study was conducted with air dried $2 \mathrm{~mm}$-sieved surface soil samples $(0-20 \mathrm{~cm})$ collected from roadside Morena district. The collected soil samples will be oven dried, grounded in a paste and morter and will be passed through a $1 \mathrm{~mm}$ sieve. They will be analysed for the number of physical and chemical parameters as per standard procedure [12-13].

The heavy metals $(\mathrm{Cu}, \mathrm{Cr}, \mathrm{Fe}, \mathrm{Pb}, \mathrm{Zn}$ and $\mathrm{Mn}$ ) content of the soil samples were extracted using the wet-acid digestion method. Digestion of soil sample for heavy metals was carried out with a mixture of Conc. $\mathrm{HCLO}_{4}$ and $\mathrm{HNO}_{3}$ at a ratio of 2:1 and heavy metals were extracted using $0.5 \mathrm{~m}$ HCL [14]. The heavy metals concentrations in the supernatant were determined using Atomic Absorption spectrophotometer meter Alpha 4 model.

\section{RESULTS AND DISCUSSION}

Heavy metals $(\mathrm{Cu}, \mathrm{Cr}, \mathrm{Fe}, \mathrm{Pb}, \mathrm{Zn}$ and $\mathrm{Mn}$ ) content at $50 \mathrm{~cm}-1 \mathrm{~m}$ (point $\mathrm{A}$ ) and 30m (point B) from the roadside are shown in Tables 1 and 2, respectively. The tables show higher mean values of heavy metals in Table $1(50 \mathrm{~cm}-1 \mathrm{~m})$ compared to Table $2(30 \mathrm{~m})$. Mean values of $\mathrm{Cu}, \mathrm{Cr}, \mathrm{Fe}$, $\mathrm{Pb}, \mathrm{Zn}$ and $\mathrm{Mn}$ were $19.03,34.36,15.61,34.425,5.72$ and $32.53 \mathrm{mgkg}^{-1}$ respectively at point $\mathrm{A}$ $(50 \mathrm{~cm}-1 \mathrm{~m})$ while $12.9(\mathrm{Cu}), 24.6(\mathrm{Cr}), 10.5(\mathrm{Fe}), 30.3(\mathrm{~Pb}), 2.27(\mathrm{Zn})$ and $22.3(\mathrm{Mn}) \mathrm{mgkg}^{-1}$ where $^{-1}$ obtained at point $\mathrm{B}(30 \mathrm{~m})$. However, observed values of $\mathrm{Pb}$ at $\mathrm{B} 2$ and $\mathrm{B} 11$ values were higher than those at points A2 and A11 respectively. Generally, results showed that as distance from the roadside increase heavy metal content of the soil decrease.

The concern over heavy metal pollution of soils is based on many reasons. First as a result of human activity heavy metals may accumulate in the soil environment to a point where their levels are toxic to plants. Second their off-site movement either to surface water or to ground water has the potential for contamination of drinking water resources. Thirdly heavy metal might accumulate in the food-chain and affect the health of people who eat food grown on metal contaminated soils.

The higher level of heavy metals observed at $50 \mathrm{~cm}-1 \mathrm{~m}$ away from the roadside could be attributed in part to heavy metal emission from vehicle exhaust in particulate form which are forced to settle under gravity closer to the road edge or due to non-point contamination sources most commonly vehicle exhaust and wear of vehicle parts. Studies showed that decreasing heavy metal concentration with increasing distance from the road [15]. The uptake of these heavy metals by plants results in bioaccumulation of these elements which according to [16] and [17] cause a serious risk to human health when plant - based food stuff are consumed. 


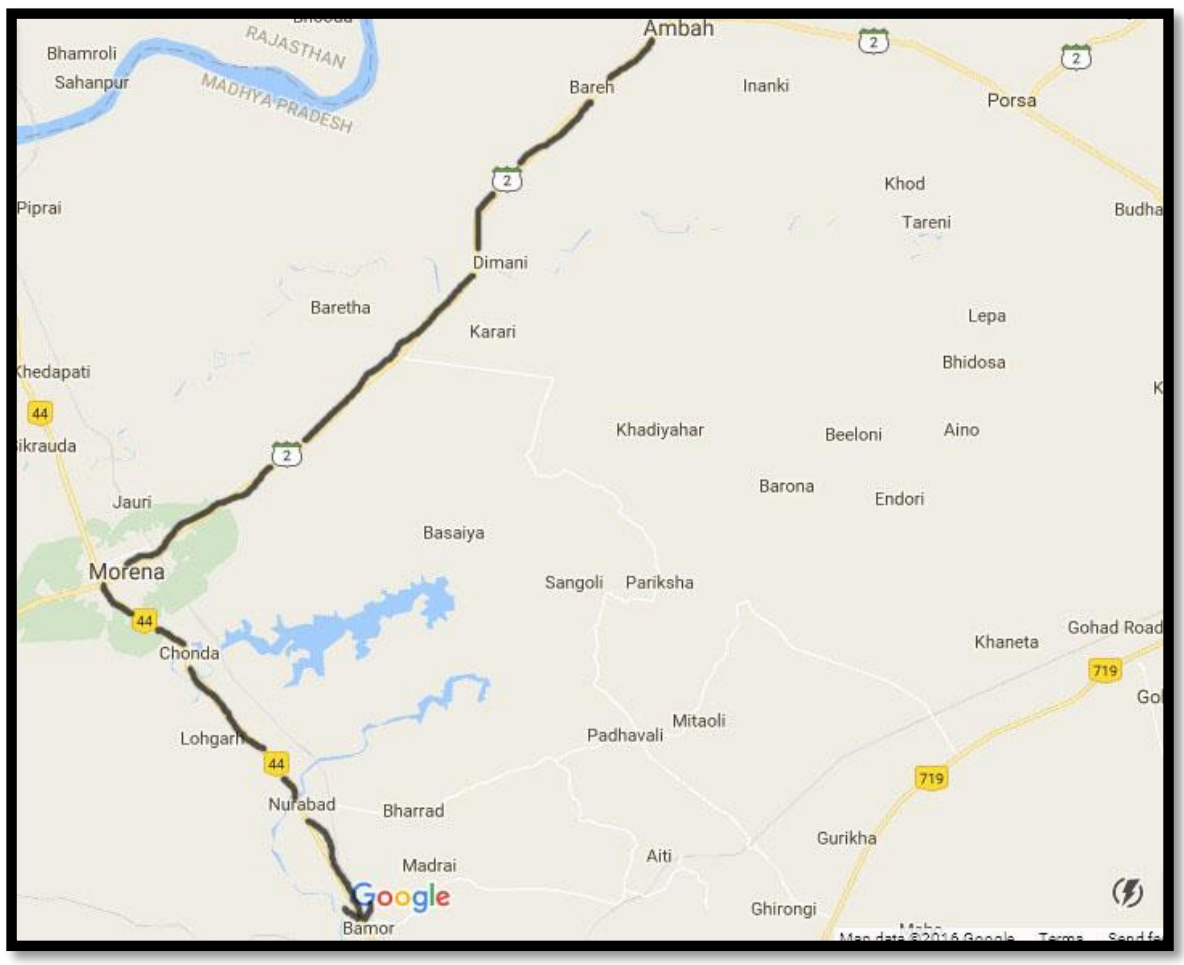

Figure 1: Map showing study area Morena district

Table 1: Heavy metal concentration on point A $(50 \mathrm{~cm}-1 \mathrm{~m})$ away from the roadside $\left(\mathrm{mgkg}^{-1}\right)$

\begin{tabular}{|l|l|l|l|l|l|l|}
\hline Sampling points & $\mathbf{C u}$ & $\mathbf{C r}$ & $\mathbf{F e}$ & $\mathbf{P b}$ & $\mathbf{Z n}$ & $\mathbf{M n}$ \\
\hline $\mathbf{1}$ & 6.5 & 40.2 & 22.2 & 45.3 & 7.12 & 41.12 \\
\hline $\mathbf{2}$ & 17.1 & 31.6 & 18.6 & 36.4 & 6.15 & 38.2 \\
\hline $\mathbf{3}$ & 24.6 & 29.3 & 20.2 & 38.6 & 4.26 & 27.65 \\
\hline $\mathbf{4}$ & 22.7 & 37.4 & 15.3 & 28.2 & 5.25 & 28.8 \\
\hline $\mathbf{5}$ & 20.4 & 42.8 & 10.6 & 33.4 & 5.16 & 55.16 \\
\hline $\mathbf{6}$ & 16.8 & 38.8 & 18.4 & 22.8 & 5.21 & 42.62 \\
\hline $\mathbf{7}$ & 12.9 & 28.3 & 14.8 & 25.4 & 4.24 & 32.52 \\
\hline $\mathbf{8}$ & 26.8 & 27.2 & 9.5 & 39.6 & 6.28 & 17.46 \\
\hline $\mathbf{9}$ & 21.5 & 33.2 & 11.5 & 31.1 & 7.23 & 31.84 \\
\hline $\mathbf{1 0}$ & 16.6 & 41.5 & 15.3 & 48.2 & 5.18 & 25.16 \\
\hline $\mathbf{1 1}$ & 19.2 & 27.3 & 12.6 & 40.6 & 6.24 & 30.42 \\
\hline
\end{tabular}




\begin{tabular}{|l|l|l|l|l|l|l|}
\hline 12 & 23.3 & 34.8 & 18.4 & 23.5 & 6.32 & 19.42 \\
\hline Mean & $\mathbf{1 9 . 0 3}$ & $\mathbf{3 4 . 3 6}$ & $\mathbf{1 5 . 6 1}$ & $\mathbf{3 4 . 4 2 5}$ & $\mathbf{5 . 7 2}$ & $\mathbf{3 2 . 5 3}$ \\
\hline
\end{tabular}

Table 2: Heavy metal concentration on point B (30m) away from the roadside $\left(\mathrm{mgkg}^{-1}\right)$

\begin{tabular}{|l|l|l|l|l|l|l|}
\hline Sampling points & $\mathbf{C u}$ & $\mathbf{C r}$ & $\mathbf{F e}$ & $\mathbf{P b}$ & $\mathbf{Z n}$ & $\mathbf{M n}$ \\
\hline $\mathbf{1}$ & 3.2 & 30.4 & 16.4 & 24.6 & 4.15 & 30.21 \\
\hline $\mathbf{2}$ & 10.4 & 21.6 & 12.2 & 45.3 & 1.18 & 28.2 \\
\hline $\mathbf{3}$ & 15.6 & 19.4 & 17.6 & 27.6 & 0.97 & 17.35 \\
\hline $\mathbf{4}$ & 16.7 & 31.7 & 9.5 & 24.8 & 1.26 & 22.8 \\
\hline $\mathbf{5}$ & 18.6 & 28.3 & 4.6 & 20.2 & 2.45 & 35.26 \\
\hline $\mathbf{6}$ & 14.7 & 27.5 & 8.1 & 12.3 & 1.32 & 32.32 \\
\hline $\mathbf{7}$ & 8.5 & 18.6 & 11.8 & 22.5 & 0.68 & 22.12 \\
\hline $\mathbf{8}$ & 11.3 & 20.8 & 3.6 & 32.4 & 3.48 & 10.26 \\
\hline $\mathbf{9}$ & 5.6 & 15.3 & 9.4 & 28.3 & 4.21 & 21.28 \\
\hline $\mathbf{1 0}$ & 10.6 & 34.7 & 11.7 & 31.7 & 1.25 & 15.14 \\
\hline $\mathbf{1 1}$ & 19.2 & 16.8 & 7.4 & 53.8 & 3.68 & 20.16 \\
\hline $\mathbf{1 2}$ & 20.5 & 30.2 & 14.6 & 40.5 & 2.68 & 12.52 \\
\hline $\mathbf{1 2 . 9}$ & $\mathbf{2 4 . 6}$ & $\mathbf{1 0 . 5}$ & $\mathbf{3 0 . 3}$ & $\mathbf{2 . 2 7}$ & $\mathbf{2 2 . 3}$ \\
\hline & & & & & & \\
\hline
\end{tabular}

\section{CONCLUSION}

The risk posed by heavy metals to food safety and the environment is of great concern to governments and society in many countries. The cumulative contamination effect of long-term exposure to traffic activities cannot be neglected, more importantly the roadside farmland soil, which is associated with the food chain and public health. The most probable source of these contaminants is the vehicular traffic run on this way. The results indicated that the heavy metals concentrations of $\mathrm{Cu}, \mathrm{Cr}, \mathrm{Fe}, \mathrm{Pb}, \mathrm{Zn}$ and $\mathrm{Mn}$ in roadside soil matrix increased at first and then decreased with the distance increases away from the roadside. The study showed elevated heavy metal concentration at $50 \mathrm{~cm}-1 \mathrm{~m}$ from the roadside. 
Results from the study showed that agricultural soil nearer roadside contains higher levels of heavy metals and constitute health risk to human and animal health when plants - based food stuff grown along the area consumed.

\section{REFERENCES}

[1] C. L. Ndiokwere. A study of heavy metal pollution from motor vehicle emissions and its effects on roadside soil, vegetation and crops in Nigeria. Env. Pollut. (Series B), vol. 7, 35-42, (1984).

[2] J. T. Nyangababo and J. W. Hamya. The deposition of lead, cadmium, zinc and copper from motor traffic on Brachiariaenimi and soil along a major Bombo road to Kampala City, Int. J. Env. Stud. Vol. 27, 115-119, (1986).

[3] Bhatia and G. N. Choudri. Impact of automobile effusion on plant and soil, Int. J. Ecol. and Env. Sc., vol. 17, 121-127, (1991).

[4] Poszyler-Adamska, A and A. Czemiak. Biological chemical indication of roadside ecotonic zones. L. Environ. Engg. Landscape Management, vol. 15, no. 2, 113a-118a, (2007).

[5] Turer D G, Maynard B J. Heavy metal contamination in highway soils. Clean Tech. Environ. Policy; 4:235 - 245, (2003).

[6] Ma HW, Hung ML, Chen PC. A systemic health risk assessment for the chromium cycle in Taiwan. Environment International 10, 1016-1023, (2006).

[7] E. S. Abechi., O. J. Okunola, S. M. J. Zubairu, A. A. Usman and E. Apene. Evaluation of heavy metals in roadside soils of major streets in Jos metropolis, Nigeria. Journal of Environmental Chemistry and Ecotoxicology, vol. 2, no. 6, 2010, 98-102. (2010).

[8] H. M. Naser., S. Sultana, R. Gomes and S. Noor. Heavy metal pollution of soil and vegetable grown near road side at Gazipur Bangladesh, J. Agril. Res., vol. 37, no. 1, 917, (2012).

[9] S. S. Ahmad and S. Erum. Integrated assessment of heavy metals pollution along motorway M-2.Soil \& Environ., vol. 29, no. 2, 110-116, (2010).

[10] M. Qasem and A. Kamal. Contamination of Roadside Soil, Plants, and Air with Heavy Metals in Jordan, A Comparative Study., Turk J. Chem., vol. 23, 209-220, (1998).

[11] H. Arslan and A. Murat. Heavy metal content of roadside soil in Mersin, Turkey. Fresenius Environmental Bulletin, vol. 15 no. 1, 15-20, (2006).

[12] M.L. Jackson, Soil Chemical Analysis, Prentice-Hall (India), New Delhi, (1967).

[13] T.C. Baruah and H.P. Borthakur, A Textbook of Soil Chemical Analysis, Vikas Publishing, New Delhi, (1967).

[14] Lacatusu R. Application levels of soil contamination and pollution with Heavy Metals. European Soil Bureau Research Report No. 4., (2002).

[15] Hay-Garth P M, Jones K C. Atomospheric deposition of metal to agriculture surface. In Adriano, D. C., (eds). Biochemistry of trace metals. C. R. C. Press, Boca Raton.; $249-$ 226, (1992).

[16] Alloway B S. Heavy metals in Soil Halsteed press, John Wiley and Sons Inc. London;: 339, (1996).

[17] Kabata - pendias A, Pendias H. Trace element in soil and plants. C. R. K. Press Boca Raton FL (1984). 